\title{
KEWENANGAN BAWASLU DALAM PILKADA 2020 PASCA PUTUSAN MAHKAMAH KONSTITUSI NOMOR 48/PUU-XVII/2019
}

\author{
M. Taufan Perdana, Moh. Alfaris, Anik Iftitah; Fakultas Hukum Universitas Islam Balitar Blitar, \\ Jatim; E-mail: taufan.fhunisba@gmail.com
}

\begin{abstract}
Abstrak
Pemilihan Umum Kepala Daerah (Pilkada) 2020 sebagai proses kedaulatan rakyat di tingkat lokal untuk mewujudkan negara yang demokratif di tingkat daerah, menuntut penyelenggaraan pemilihan yang profesional dan dapat dipertanggungjawabkan, membutuhkan keintegritasan lembaga pengawasan penyelenggaraan pemilihan (Bawaslu), guna menjamin transparansi dan efisiensi penyelenggaraan. Namun, ada perbedaan kelembagaan Bawaslu di tingkat kabupaten/kota dalam UU Pilkada dan UU Pemilu sehingga timbul Putusan Mahkamah Konstitusi Nomor 48/PUU-XVII/2019 tentang Pengujian UU Pilkada terhadap UUD NRI 1945. Melalui penelitian hukum normatif, diketahui bahwa pasca putusan MK 48/PUU-XVII/2019, kewenangan pembentukan dan penetapan Panwas Kabupaten/Kota, bukan dibentuk dan ditetapkan oleh Bawaslu Provinsi, melainkan oleh Bawaslu (Pusat); nomenklatur Panwas Kabupaten/Kota dalam UU Pilkada harus dipahami pula sebagai Bawaslu Kabupaten/Kota; sifat kelembagaannya di tingkat kabupaten/kota menjadi permanen, bukan lagi ad hoc, dengan jumlah anggota sesuai UU Pemilu.
\end{abstract}

Kata Kunci: Kewenangan, Bawaslu, Putusan MK 48/PUU-XVII/2019

\section{Abstract}

Regional Head General Election (Pilkada) 2020 as process of popular sovereignty at the local level to create a democratic state at the regional level, demanding professional and accountable elections, requiring the integrity of the Election Supervisory Body (Bawaslu), to ensure transparency and efficiency of the organization. However, there are institutional differences in Bawaslu at the district / city level in the Election Law and the Election Law so that a Constitutional Court Decision Number 48 / PUU-XVII / 2019 regarding Pilkada Law Testing against the 1945 Constitution of the Republic of Indonesia. Through normative legal research, it is known that after the Constitutional Court's decision 48 / PUU-XVII / 2019, the authority for the formation and determination of Regency / City Panwas, is not formed and determined by the Provincial Bawaslu, but by the Bawaslu (Central); Regency / City Panwas nomenclature in the Regional Election Law must also be understood as Regency / City Bawaslu; the institutional nature at the regency/city level is permanent, no longer ad hoc, with a number of members according to the Election Law.

Keywords: Authority, Bawaslu, Constitutionnal Court's Decision 48/PUU-XVII/2019

\section{PENDAHULUAN}

\section{Latar Belakang}

Pemilihan Umum Kepala Daerah (Pilkada) merupakan proses kedaulatan rakyat ditingkat lokal/ daerah yang diatur berdasarkan Pasal 18 ayat (4) Undang-Undang Dasar Negara Republik Indonesia Tahun 1945 (UUD NRI 1945) yang merupakan hak konstitusional seluruh warga negara Indonesia. Sejak Juni 2005 untuk pertama kalinya dalam sejarah bangsa Indonesia menyelenggarakan Pilkada secara langsung oleh rakyat. Sebelumnya, di bawah Undang-Undang Republik Indonesia Nomor 22 Tahun 1999 tentang Pemerintahan Daerah (UU Pemda 22/1999), pemilihan gubernur, bupati, dan walikota beserta wakil-wakil mereka dilakukan oleh Dewan Perwakilan Rakyat Daerah (DPRD) sesuai tingkatnya masing-masing. Melalui Undang-Undang Republik Indonesia Nomor 32 Tahun 2004 tentang Pemerintahan Daerah (UU Pemda 32/2004), mekanisme 
pemilihan kepala daerah oleh DPRD yang dianut UU Pemda 22/1999 diubah secara drastis menjadi pemilihan secara langsung oleh rakyat.

Kepala Daerah terpilih hasil Pilkada sudah seharusnya mempertanggungjawabkan kepercayaan rakyat yang diberikan kepada mereka dalam bentuk menjalankan pemerintahan yang pro rakyat. Pro rakyat artinya terus mendengarkan suara rakyat, baik itu berupa keluhan, kritik, maupun saran yang kemudian diwujudkan dalam bentuk kebijakan, program, dan keputusan-keputusan politik. Suara rakyat adalah suara yang harus terus didengarkan dan dihargai, tidak hanya saat Pemilihan Umum (Pemilu) saja, untuk kemudian diartikulasikan oleh pemimpin daerah yang terpilih. Suara rakyat adalah beban yang harus dipikul, tanggung jawab yang harus diemban oleh setiap orang yang mendapatkan suara mayoritas. ${ }^{1}$ Hal tersebut salah satunya hanya dapat dicapai melalui Pemilu, termasuk di dalamnya Pilkada yang demokratis.

Pilkada yang demokratis senantiasa diupayakan agar pelaksanaannya efektif, efisien, dan menghasilkan pemimpin-pemimpin di daerah yang representatif bagi kepentingan rakyat di daerah yang dipimpinnya. Salah satu upaya untuk meningkatkan kualitas pelaksanaan Pilkada adalah dengan menerapkan sistem Pilkada Serentak. Indonesia telah dan akan melaksanakan Pilkada secara serentak. Diresmikan oleh Komisi Pemilihan Umum (KPU) pada April 2015, Pilkada serentak akan dilakukan dalam tiga gelombang. Gelombang pertama, 9 Desember 2015, ditujukan bagi kepala daerah yang memasuki akhir masa jabatan 2015 dan semester pertama 2016. Gelombang kedua dijadwalkan pada Februari 2016 untuk kepala daerah yang masa jabatannya berakhir pada semester kedua 2016 dan tahun 2017. Sementara gelombang ketiga akan dilaksanakan pada Juni 2018, ditujukan bagi kepala daerah yang akhir masa jabatannya jatuh pada 2018 dan 2019. Pilkada serentak gelombang keempat akan dilaksanakan pada 2020 untuk memilih kembali kepala daerah hasil pemilihan tahun 2015. Gelombang kelima Pilkada adalah tahun 2022 untuk kepala daerah hasil pemilihan 2017. Gelombang keenam akan dilaksanakan pada 2023 untuk kepala daerah hasil pemilihan tahun 2018. Dan, Pilkada serentak secara nasional diharapkan dapat dilaksanakan pada 2027.

Pilkada 2020 sebagai Pilkada serentak gelombang keempat, dalam Peraturan Komisi Pemilihan Umum Republik Indonesia Nomor 15 Tahun 2019 tentang Tahapan, Program dan Jadwal Penyelenggaraan Pemilihan Gubernur dan Wakil Gubernur, Bupati dan Wakil Bupati, dan/atau Walikota dan Wakil Walikota (PKPU 15/2019) dikenal dengan istilah "Pemilihan", dengan tahapan pemilihan terdiri atas tahapan persiapan dan tahapan penyelenggaraan, ${ }^{2}$ tertanggal sejak 30 September 2019 sampai selesai (penetapan calon terpilih), tahap persiapan pada rentang tanggal 30 September 2019 sampai 22

1 Prayudi, Ahmad Budiman,Aryojati Ardipandanto, Editor: Syamsuddin Haris, (2017), Dinamika Politik Pilkada Serentak, Jakarta: Pusat Penelitian Badan Keahlian DPR RI.

2 Baca Pasal 3, 4, dan 5 Peraturan Komisi Pemilihan Umum Republik Indonesia Nomor 15 Tahun 2019 tentang Tahapan, Program dan Jadwal Penyelenggaraan Pemilihan Gubernur dan Wakil Gubernur, Bupati dan Wakil Bupati, dan/atau Walikota dan Wakil Walikota (PKPU 15/2019). 
September 2020, dan tahap penyelenggaraan pada rentang tanggal 26 Oktober 2019 sampai penetapan calon terpilih. ${ }^{3}$

Pilkada sebagai salah satu upaya mewujudkan negara yang demokratif di tingkat daerah, harus dapat dilaksanakan dengan baik, menuntut penyelenggara pemilihan umum yang profesional dan dapat dipertanggungjawabkan, guna menjamin transparansi dan efisiensi penyelenggaraan Pilkada, sehingga sangat membutuhkan peranan lembaga yang mengawasi penyelenggaraan atau pelaksanaan seluruh tahapan Pilkada yang bernama Bawaslu.

Bawaslu menurut Undang-Undang Republik Indonesia Nomor 10 Tahun 2016 tentang Perubahan Kedua atas Undang-Undang Nomor 1 Tahun 2015 tentang Penetapan Peraturan Pemerintah Pengganti Undang-Undang Nomor 1 Tahun 2014 tentang Pemilihan Gubernur, Bupati, dan Walikota (UU Pilkada) merupakan singkatan dari Badan Pengawas Pemilihan Umum, yaitu lembaga penyelenggara pemilihan umum yang bertugas mengawasi penyelenggaraan pemilihan umum di seluruh wilayah Negara Kesatuan Republik Indonesia. ${ }^{4}$ Sedangkan Bawaslu menurut Undang-Undang Republik Indonesia Nomor 7 Tahun 2017 tentang Pemilihan Umum (UU Pemilu) merupakan singkatan dari Badan Pengawas Pemilu dengan pengertian yang sama dengan UU Pilkada. ${ }^{5}$ Berpengertian sama, namun berkonsep kelembagaan berbeda.

Konsep kelembagaan Bawaslu berdasarkan UU Pemilu dibanding UU Pilkada mengalami perubahan. Perubahan-perubahan itu mencakup:

1. penambahan jumlah keanggotaan Bawaslu di tingkat provinsi dan Kabupaten/Kota;

2. Perubahan status Bawaslu di tingkat Kabupaten/Kota dari yang bersifat adhoc menjadi permanen;

3. Adanya penegasan sifat keorganisasian Bawaslu yang bersifat hierarkis pada UU Pemilu, dengan menekankan fungsi supervisi dan pembinaan;

4. Berdasarkan UU Pemilu, memunculkan Peraturan Presiden tentang organisasi sekretariat lembaga Bawaslu.

Perbedaan nomenklatur kelembagaan Bawaslu pada UU Pilkada dan UU Pemilu seperti yang tertulis tersebut di atas, menimbulkan ketidakpastian hukum kelembagaan Bawaslu, terutama kelembagaan Bawaslu di level kabupaten/kota yang bisa berimplikasi pada terhambatnya kinerja. Hal ini pulalah yang menjadi salah satu latar belakang timbulnya Putusan Mahkamah Konstitusi Nomor 48/PUU-XVII/2019.

Putusan Mahkamah Konstitusi Nomor 48/PUU-XVII/2019 tentang Pengujian Undang-Undang Nomor 1 Tahun 2015 tentang Penetapan Peraturan Pemerintah Pengganti Undang-Undang Nomor 1 Tahun 2014 tentang Pemilihan Gubernur, Bupati,

\footnotetext{
${ }^{3}$ Lihat Lampiran Peraturan Komisi Pemilihan Umum Republik Indonesia Nomor 15 Tahun 2019 tentang Tahapan, Program dan Jadwal Penyelenggaraan Pemilihan Gubernur dan Wakil Gubernur, Bupati dan Wakil Bupati, dan/atau Wali Kota dan Wakil Wali Kota Tahun 2020.

${ }^{4}$ Baca Pasal 1 angka 10 Undang-Undang Nomor 1 Tahun 2015 tentang Penetapan Peraturan Pemerintah Pengganti Undang-Undang Nomor 1 Tahun 2014 tentang Pemilihan Gubernur, Bupati, dan Walikota (UU Pilkada).

${ }^{5}$ Lihat Pasal 1 angka 17 Undang-Undang Republik Indonesia Nomor 7 Tahun 2017 tentang Pemilihan Umum (UU Pemilu).
} 
dan Walikota Menjadi Undang-Undang sebagaimana telah diubah dengan UndangUndang Nomor 8 Tahun 2015 tentang Perubahan Atas Undang-Undang Nomor 1 Tahun 2015 tentang Penetapan Peraturan Pemerintah Pengganti Undang-Undang Nomor 1 Tahun 2014 tentang Pemilihan Gubernur, Bupati, dan Walikota Menjadi Undang-Undang sebagaimana telah diubah terakhir dengan Undang-Undang Nomor 10 Tahun 2016 tentang Perubahan Kedua Atas Undang-Undang Nomor 1 Tahun 2015 tentang Penetapan Peraturan Pemerintah Pengganti Undang-Undang Nomor 1 Tahun 2014 tentang Pemilihan Gubernur, Bupati, dan Walikota Menjadi Undang-Undang terhadap UndangUndang Dasar Negara Republik Indonesia Tahun 1945, antara lain menyatakan frasa Panwas Kabupaten/Kota tidak mempunyai kekuatan hukum mengikat secara bersyarat sepanjang tidak dimaknai Bawaslu Kabupaten/Kota, bahwa frasa Panwaslu Kabupaten/Kota dalam UU Pilkada tidak berlaku dan tidak lagi menjadi rumusan norma a quo. Hal ini berarti bahwa frasa Panwaslu Kabupaten/Kota dalam UU Pilkada harus dimaknai sebagaimana frasa Bawaslu Kabupaten/Kota dalam UU Pemilu.

Mengingat Putusan Mahkamah Konstitusi yang mempunyai konsekuensi langsung memperoleh kekuatan hukum tetap sejak diucapkan dan tidak ada upaya hukum yang dapat ditempuh ${ }^{6}$, menjadi sangat penting untuk menganalisis pengaturan kewenangan lembaga yang mengawasi pemilihan umum dalam pelaksanaan Pilkada 2020 pasca Putusan Mahkamah Konstitusi Nomor 48/PUU-XVII/2019 yang menganulir frasa Panwaslu Kabupaten/Kota dalam UU Pilkada.

\section{Rumusan Masalah}

Masalah yang menjadi fokus penelitian ini yaitu kewenangan Bawaslu dalam Pilkada 2020 Pasca Putusan Mahkamah Konstitusi Nomor 48/PUU-XVII/2019 tentang Pengujian UU Pilkada terhadap UUD NRI 1945.

\section{METODE PENELITIAN}

Penelitian ini berangkat dari pokok persoalan kewenangan lembaga pengawas pemilihan umum (Bawaslu) dalam Pemilihan Kepala Daerah (Pilkada) pasca Putusan Mahkamah Konstitusi Nomor 48/PUU-XVII/2019 tentang Pengujian UU Pilkada terhadap UUD NRI 1945 (Putusan MK 48/PUU-XVII/2019) yang menjawab ketidakpastian hukum akibat adanya ketidakharmonisan substansi terkait Bawaslu dalam UU Pilkada dan UU Pemilu. Untuk menjawab permasalahan yang telah dirumuskan dalam penelitian ini, digunakan penelitian hukum normatif.

Penelitian hukum normatif di dalam literatur hukum asing biasa disebut dengan legal research dan tanpa tambahan makna lain, menurut sebagian penstudi hukum dikatakan sebagai penelitian hukum yang murni (the pure legal research). ${ }^{7}$ Penelitian

\footnotetext{
${ }^{6}$ Baca Mohammad Agus Maulidi. (2017). Problematika Hukum Implementasi Putusan Final dan Mengikat Mahkamah Konstitusi Perspektif Negara Hukum. Jurnal Hukum Ius Quia Iustum No. 4 Vol. 24 Oktober 2017, h. 536.

7 Depri Liber Sonata. (2014). "Metode Penelitian Hukum Normatif dan Empiris: Karakteristik Khas dari Metode Meneliti Hukum". Fiat Justisia Jurnal Ilmu Hukum, Volume 8 No. 1, Januari-Maret 2014. h. 28.
} 
hukum normatif (normative law research) menggunakan studi kasus hukum normatif berupa produk perilaku hukum. ${ }^{8}$ Penelitian hukum normatif mencitrakan hukum sebagai disiplin preskriptif yang melihat hukum dari sudut pandang norma-normanya. ${ }^{9}$ Dalam konteks penelitian ini, pokok kajiannya adalah Putusan MK No. 48/PUU-XVII/2019, UU Pilkada, dan UU Pemilu.

Dalam penelitian pada umumnya dibedakan antara data yang diperoleh secara langsung dari masyarakat dan dari bahan-bahan pustaka. Yang diperoleh langsung dari masyarakat dinamakan data primer (atau data dasar), sedangkan yang diperoleh dari bahan-bahan pustaka lazimnya dinamakan data sekunder. ${ }^{10}$

Sesuai dengan tipe penelitian yuridis normatif maka data yang dikumpulkan adalah data sekunder. Data sekunder di bidang hukum yang digunakan dalam penelitian ini mencakup tiga bagian yaitu:

a. Bahan Hukum Primer yaitu bahan-bahan hukum yang mengikat, terdiri dari:

1) Putusan Mahkamah Konstitusi Nomor 48/PUU-XVII/2019 tentang Pengujian Undang-Undang Nomor 1 Tahun 2015 tentang Penetapan Peraturan Pemerintah Pengganti Undang-Undang Nomor 1 Tahun 2014 tentang Pemilihan Gubernur, Bupati, dan Walikota Menjadi Undang-Undang sebagaimana telah diubah dengan Undang-Undang Nomor 8 Tahun 2015 tentang Perubahan Atas Undang-Undang Nomor 1 Tahun 2015 tentang Penetapan Peraturan Pemerintah Pengganti UndangUndang Nomor 1 Tahun 2014 tentang Pemilihan Gubernur, Bupati, dan Walikota Menjadi Undang-Undang sebagaimana telah diubah terakhir dengan UndangUndang Nomor 10 Tahun 2016 tentang Perubahan Kedua Atas Undang-Undang Nomor 1 Tahun 2015 tentang Penetapan Peraturan Pemerintah Pengganti UndangUndang Nomor 1 Tahun 2014 tentang Pemilihan Gubernur, Bupati, dan Walikota Menjadi Undang-Undang terhadap Undang-Undang Dasar Negara Republik Indonesia Tahun 1945.

2) Undang-Undang Republik Indonesia Nomor 10 Tahun 2016 tentang Perubahan Kedua atas Undang-Undang Nomor 1 Tahun 2015 tentang Penetapan Peraturan Pemerintah Pengganti Undang-Undang Nomor 1 Tahun 2014 tentang Pemilihan Gubernur, Bupati, dan Walikota (UU Pilkada).

3) Undang-Undang Republik Indonesia Nomor 7 Tahun 2017 tentang Pemilihan Umum.

4) Undang-Undang Republik Indonesia Nomor 15 Tahun 2019 tentang Perubahan Atas Undang-Undang Republik Indonesia Nomor 12 tahun 2011 tentang Pembentukan Peraturan Perundang-Undangan.

\footnotetext{
8 R.A. Granita Ramadhani. (2009). Analisa Aspek Metodologi. FH UI. h. 57.

${ }^{9}$ Depri Liber Sonata, Op. Cit. h.25.

10 Soerjono Soekanto dan Sri Mamudji. (2011). Penelitian Hukum Normatif. Suatu Tinjauan Singkat, Jakarta: Raja Grafindo Persada. h. 12.
} 
5) Peraturan Komisi Pemilihan Umum Republik Indonesia Nomor 15 Tahun 2019 tentang Tahapan, Program dan Jadwal Penyelenggaraan Pemilihan Gubernur dan Wakil Gubernur, Bupati dan Wakil Bupati, dan/atau Walikota dan Wakil Walikota.

6) Surat Edaran Nomor 0410/K.Bawaslu/HK.05/XI/2019 tentang Pelaksanaan Tugas dan Wewenang Pengawasan Penyelenggaraan Pemilihan Gubernur dan Wakil Gubernur, Bupati dan Wakil Bupati, serta Walikota dan Wakil Walikota Tahun 2020.

b. Bahan Hukum Sekunder adalah bahan hukum yang terdiri atas buku-buku teks yang ditulis para ahli hukum yang berpengaruh, jurnal-jurnal hukum, pendapat para sarjana, kasus-kasus hukum, yurispudensi, dan hasil-hasil simposium mutakhir yang berkaitan dengan penelitian. ${ }^{11}$

c. Bahan hukum tersier adalah bahan hukum yang memberikan petunjuk atau penjelasan terhadap bahan hukum primer dan bahan hukum sekunder seperti kamu hukum, ensiklopedia, dan lain-lain. ${ }^{12}$

Teknik pengumpulan data dilakukan dengan studi pustaka. Bahan hukum yang telah terkumpul diklasifikasikan, dianalisis dengan cara menggali asas, nilai serta norma pokok yang terkandung di dalamnya. Selanjutnya dilakukan cross-check dengan peraturan perundang-undangan yang lain untuk menemukan taraf sinkronisasi/harmonisasinya, adakah inkonsistensi di antara peraturan perundangundangan tersebut. Analisis data tersebut dilakukan secara kualitatif melalui penelaahan logika berpikir secara deduktif. ${ }^{13}$ Hasil penelitian disajikan dalam bentuk uraian-uraian yang tersusun secara sistematis.

\section{PEMBAHASAN}

Istilah Pemilihan Kepala Daerah 2020 (Pilkada 2020) dalam Undang-Undang Republik Indonesia Nomor 10 Tahun 2016 tentang Perubahan Kedua atas UndangUndang Nomor 1 Tahun 2015 tentang Penetapan Peraturan Pemerintah Pengganti Undang-Undang Nomor 1 Tahun 2014 tentang Pemilihan Gubernur, Bupati, dan Walikota Menjadi Undang-Undang (UU Pilkada) menggunakan istilah "pemilihan". Istilah Pemilihan dalam UU Pilkada merupakan pemilihan Gubernur, Bupati, dan Walikota. Pemilihan adalah pelaksanaan kedaulatan rakyat di Provinsi dan Kabupaten/Kota untuk memilih Gubernur, Bupati, dan Walikota secara langsung dan demokratis. ${ }^{14}$ Disebut demokratis apabila mekanisme pemilihan kepala daerahnya

11 Johnny Ibrahim. (2011). Teori dan Metode Penelitian Hukum Normatif. Cet. 4, Malang: Bayumedia Publishing, 2011, h. 296.

12 Ibid.

${ }^{13}$ Baca Prof. Dr. Suteki, S.H.,M.Hum., dan Galang Taufani, S.H.,M.H (2018). Metodologi Penelitian Hukum (Filsafat, Teori dan Praktik). Depok: Rajawali Pers. h. 267.

${ }^{14}$ Lihat Pasal 1 angka 1 Undang-Undang Republik Indonesia Nomor 10 Tahun 2016 tentang Perubahan Kedua atas Undang-Undang Nomor 1 Tahun 2015 tentang Penetapan Peraturan Pemerintah Pengganti Undang-Undang Nomor 1 Tahun 2014 tentang Pemilihan Gubernur, Bupati, dan Walikota Menjadi Undang-Undang (UU Pilkada). 
memenuhi parameter adanya rotasi kekuasaan, rekrutmen secara terbuka, dan akuntabilitas publik. ${ }^{15}$

Untuk mewujudkan amanah tersebut di atas, yang juga sesuai dengan ketentuan Pasal 18 ayat (4) Undang-Undang Dasar Republik Indonesia Tahun 1945 (UUD NRI 1945), maka diperlukan satu lembaga pengawas pemilihan, yaitu Bawaslu. Bawaslu merupakan singkatan dari Badan Pengawas Pemilihan Umum. Yaitu lembaga penyelenggara pemilihan umum yang bertugas mengawasi penyelenggaraan pemilihan umum di seluruh wilayah Negara Kesatuan Republik Indonesia.

Bawaslu sebagai bagian dari lembaga penyelenggara pemilihan umum (penyelenggara pemilu) di Indonesia, tunduk pada Undang-Undang Republik Indonesia Nomor 15 Tahun 2011 tentang Penyelenggara Pemilihan Umum (UU Penyelenggara Pemilu). Namun, dengan diberlakukannya Undang-Undang Nomor 7 Tahun 2017 tentang Pemilihan Umum (UU Pemilu), maka UU Penyelenggara Pemilu tersebut dicabut dan dikodifikasikan dalam satu undang-undang yang secara substansi mengatur tentang kelembagaan penyelenggara Pemilu dan mekanisme mekanisme Pemilu.

Namun, ada perbedaan kelembagaan dan kewenangan Bawaslu di tingkat kabupaten/kota dalam UU Pilkada dan UU Pemilu, sehingga dalam konteks Pilkada, menimbulkan ketidakpastian sistem kelembagaan penyelenggara Pilkada yang berimbas pada kewenangannya.

Lembaga pengawas penyelenggaraan pemilihan dalam UU Pilkada, terdiri dari Bawaslu Provinsi, Panwas Kabupaten/Kota, Panwas Kecamatan, PPL, dan Pengawas TPS. Bawaslu Provinsi, Panwas Kabupaten/Kota, dan Panwas Kecamatan masingmasing beranggotakan 3 (tiga) orang. PPL berjumlah 1 (satu) orang setiap desa atau sebutan lain/kelurahan. Pengawas TPS berjumlah 1 (satu) orang setiap TPS. Panwas Kabupaten/Kota dibentuk paling lambat 1 (satu) bulan sebelum tahapan persiapan penyelenggaraan Pemilihan dimulai dan dibubarkan paling lambat 2 (dua) bulan setelah seluruh tahapan penyelenggaraan Pemilihan selesai (ad hoc).

Lembaga pengawas penyelenggaraan pemilihan dalam UU Pemilu terdiri atas Bawaslu, Bawaslu Provinsi, Bawaslu Kabupaten/Kota, Panwaslu Kecamatan, Panwaslu Kelurahan/Desa, Panwaslu LN, dan Pengawas TPS. Bawaslu, Bawaslu Provinsi, dan Bawaslu Kabupaten/ Kota bersifat tetap. Panwaslu Kecamatan, Panwaslu Kelurahan/Desa, Panwaslu LN, dan Pengawas TPS, sebegai'nana dimaksud pada ayat (1) bersifat ad hoc. Jumlah anggota Bawaslu sebanyak 5 (lima) orang, Bawaslu Provinsi sebanyak 5 (lima) atau 7 (tujuh) orang, Bawaslu Kabupaten/Kota sebanyak 3 (tiga) atau 5 (lima) orang, dan Panwaslu Kecamatan sebanyak 3 (tiga) orang.

Pandangan hukum berdasarkan asas lex specialist derogat legi general (hukum yang khusus lebih diutamakan daripada hukum yang umum) dan asas lex posteriori derogat legi priori (peraturan yang baru didahulukan daripada peraturan yang lama) ${ }^{16}$ memberikan

\footnotetext{
15 Baca Syaukani, Affan Gaffar, M. Ryass Rasyid, Otonomi Daerah dalam Negara Kesatuan, Kerjasama Pusataka Pelajar dan Pusat Kajian Etika Politik dan Pemerintahan, Yogyakarta, 2002, h. 12-13.

16 Baca Marwan Mas, Pengantar Ilmu Hukum, Jakarta: Ghalia Indonesia, 2004, h. 98-99.
} 
pemahaman bahwa ada ketidakharmonisan substansi ${ }^{17}$ perihal kelembagaan lembaga pengawas pemilihan/pemilihan umum di tingkat kabupaten/kota dalam UU Pilkada dan UU Pemilu. Berdasarkan ketentuan UU Pemilu, komposisi keanggotaan Bawaslu Provinsi dan Bawaslu Kabupaten/Kota berjumlah 5 orang dengan kewenangannya yang terbagi dibagi ke dalam 5 (lima) divisi, yakni divisi organisasi dan sumber daya manusia, divisi pengawasan dan hubungan antar lembaga, divisi hukum dan informasi, divisi penindakan pelanggaran, dan divisi sengketa. Sedangkan, berdasarkan UU Pilkada, lembaga pengawas pemilihan dan/atau pemilihan umum di tingkat provinsi dan kabupaten/kota (Bawaslu Provinsi dan Panwas Kabupaten/Kota) hanya berjumlah 3 (tiga) orang.

Pasca Putusan Mahkamah Konstitusi Nomor 48/PUU-XVII/2019 tentang Pengujian Undang-Undang Nomor 1 Tahun 2015 tentang Penetapan Peraturan Pemerintah Pengganti Undang-Undang Nomor 1 Tahun 2014 tentang Pemilihan Gubernur, Bupati, dan Walikota Menjadi Undang-Undang sebagaimana telah diubah dengan UndangUndang Nomor 8 Tahun 2015 tentang Perubahan Atas Undang-Undang Nomor 1 Tahun 2015 tentang Penetapan Peraturan Pemerintah Pengganti Undang-Undang Nomor 1 Tahun 2014 tentang Pemilihan Gubernur, Bupati, dan Walikota Menjadi Undang-Undang sebagaimana telah diubah terakhir dengan Undang-Undang Nomor 10 Tahun 2016 tentang Perubahan Kedua Atas Undang-Undang Nomor 1 Tahun 2015 tentang Penetapan Peraturan Pemerintah Pengganti Undang-Undang Nomor 1 Tahun 2014 tentang Pemilihan Gubernur, Bupati, dan Walikota Menjadi Undang-Undang terhadap UndangUndang Dasar Negara Republik Indonesia Tahun 1945 (putusan Mahkamah Konstitusi Nomor 48/PUU-XVII/2019 tentang Pengujian UU Pilkada terhadap UUD NRI 1945), nomenklatur Panwas Kabupaten/Kota dalam UU Pilkada harus dipahami pula sebagai Bawaslu Kabupaten/Kota dalam UU Pemilu. Lebih jelasnya, tergambar dalam gambar berikut.

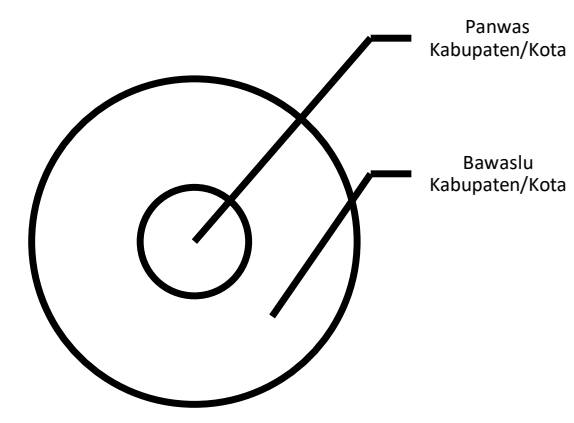

Sketsa tersebut di atas, memberikan pemahaman bahwa Bawaslu Kabupaten/Kota, juga bertindak sebagai Panwas Kabupaten/Kota dalam Pilkada. Artinya, Panwas Kabupaten/Kota bukanlah organ pengawas tersendiri, melainkan satu organ yang sama. Tidak ada perbedaan kelembagaan Panwas Kabupaten/Kota dalam UU Pilkada dan

17 Baca Wahiduddin Adams, "Harmonisasi Peraturan Perundang-Undangan di Indonesia", dalam Dinal Fedrian dkk, Dialektika Pembaharuan Sistem Hukum Indonesia, Jakarta: Komisi Yudisial Republik Indonesia, 2012, h. 137-142. 
Bawaslu Kabupaten/Kota dalam UU Pemilu. Pada saat penyelenggaraan Pemilu, bertindak sebagai Bawaslu Kabupaten/Kota sesuai UU Pemilu, dan pada saat Pilkada bertindak sebagai Panwas Kabupaten/Kota sesuai UU Pilkada. Pada saat Pemilu, lembaga pengawas penyelenggaraan Pemilu di tingkat kabupaten/kota bertugas mengawasi tahapan penyelenggaraan Pemilu dalam rangka pencegahan dan penindakan pelanggaran Pemilu sampai pelaksanaan Pemilu selesai, dan sekaligus bekerja sebagai lembaga pengawasan pemilihan pada saat penyelenggaraan Pilkada, yang bertugas dan berwenang untuk:

a. mengawasi tahapan penyelenggaraan Pemilihan yang meliputi:

1. pemutakhiran data pemilih berdasarkan data kependudukan dan penetapan Daftar Pemilih Sementara dan Daftar Pemilih Tetap;

2. pencalonan yang berkaitan dengan persyaratan dan tata cara pencalonan;

3. proses dan penetapan calon;

4. pelaksanaan Kampanye;

5. perlengkapan Pemilihan dan pendistribusiannya;

6. pelaksanaan pemungutan suara dan penghitungan suara hasil Pemilihan;

7. mengendalikan pengawasan seluruh proses penghitungan suara;

8. penyampaian surat suara dari tingkat TPS sampai ke PPK;

9. proses rekapitulasi suara yang dilakukan oleh KPU Provinsi, Kabupaten, dan Kota dari seluruh Kecamatan; dan

10. pelaksanaan penghitungan dan pemungutan suara ulang, Pemilihan lanjutan, dan Pemilihan susulan;

b. menerima laporan dugaan pelanggaran terhadap pelaksanaan peraturan perundangundangan mengenai Pemilihan;

c. menyelesaikan temuan dan laporan sengketa penyelenggaraan Pemilihan yang tidak mengandung unsur tindak pidana;

d. menyampaikan temuan dan laporan kepada KPU Provinsi dan KPU Kabupaten/Kota untuk ditindaklanjuti;

e. meneruskan temuan dan laporan yang bukan menjadi kewenangannya kepada instansi yang berwenang;

f. menyampaikan laporan kepada Bawaslu sebagai dasar untuk mengeluarkan rekomendasi Bawaslu yang berkaitan dengan adanya dugaan tindakan yang mengakibatkan terganggunya tahapan penyelenggaraan Pemilihan oleh penyelenggara di Provinsi, Kabupaten, dan Kota;

g. mengawasi pelaksanaan tindak lanjut rekomendasi Bawaslu tentang pengenaan sanksi kepada anggota KPU Provinsi dan KPU Kabupaten/Kota, sekretaris dan pegawai sekretariat KPU Provinsi dan KPU Kabupaten/Kota yang terbukti melakukan tindakan yang mengakibatkan terganggunya tahapan penyelenggaraan Pemilihan yang sedang berlangsung;

h. mengawasi pelaksanaan sosialisasi penyelenggaraan Pemilihan; dan

i. melaksanakan tugas dan wewenang lain yang diberikan oleh peraturan perundangundangan. 
Sekaligus berkewajiban untuk:

a. bersikap tidak diskriminatif dalam menjalankan tugas dan wewenangnya;

b. melakukan pembinaan dan pengawasan terhadap pelaksanaan tugas Panwas pada tingkatan di bawahnya;

c. menerima dan menindaklanjuti laporan yang berkaitan dengan dugaan adanya pelanggaran terhadap pelaksanaan peraturan perundang-undangan mengenai Pemilihan;

d. menyampaikan laporan hasil pengawasan kepada Bawaslu sesuai dengan tahapan Pemilihan secara periodik dan/atau berdasarkan kebutuhan;

e. menyampaikan temuan dan laporan kepada Bawaslu berkaitan dengan adanya dugaan pelanggaran yang dilakukan oleh KPU Provinsi atau KPU Kabupaten/Kota yang mengakibatkan terganggunya penyelenggaraan tahapan Pemilihan; dan

f. melaksanakan kewajiban lain yang diberikan oleh peraturan perundang-undangan.

Sifat kelembagaannya di tingkat kabupaten/kota menjadi permanen, bukan lagi tidak tetap (ad hoc). Hal tersebut sesuai amanah konstitusi yang mengamanatkan bahwa penyelenggara Pemilu bersifat tetap, bukan ad hoc. Artinya, tidak perlu membentuk lembaga pengawasan pemilihan (Panwas) Kabupaten/Kota di luar kelembagaan Bawaslu Kabupaten/Kota. Jumlah anggotanya, di tingkat provinsi dan kabupaten/kota, mengacu pada UU Pemilu, bukan UU Pilkada. Sebagai misal di Jawa Timur, jumlah anggota Bawaslu Provinsi maupun Panwas Kabupaten/Kota dalam Pilkada bukanlah 3 (tiga), melainkan berjumlah 7 (tujuh) untuk Bawaslu Provinsi, dan berjumlah 5 (lima) untuk Panwas Kabupaten/Kota Blitar. ${ }^{18}$ Kewenangan membentuk dan menetapkan Panwas Kabupaten/Kota, bukan menjadi kewenangan Bawaslu Provinsi, melainkan menjadi kewenangan Bawaslu (Pusat), seperti halnya pada penyelenggaraan Pemilu. ${ }^{19}$

\section{PENUTUP}

Pasca putusan Mahkamah Konstitusi Nomor 48/PUU-XVII/2019 tentang Pengujian UU Pilkada terhadap UUD NRI 1945, kewenangan pembentukan dan penetapan Panwas Kabupaten/Kota, bukanlah dibentuk dan ditetapkan oleh Bawaslu Provinsi, melainkan oleh Bawaslu (Pusat); nomenklatur Panwas Kabupaten/Kota dalam UU Pilkada harus dipahami pula sebagai Bawaslu Kabupaten/Kota; sifat kelembagaannya di tingkat kabupaten/kota menjadi permanen, bukan lagi ad hoc, dengan jumlah anggota sesuai amanah UU Pemilu.

Disharmonisasi peraturan perundang-undangan Pilkada, harus segera terhamonisasi pada semua hirarki peraturan perundang-undangan terkait, guna menjamin kepastian hukum sebagai konsekuensi negara rectstaat, sehingga tidak menggangu integritas dan keefektifan kerja Bawaslu dan semua hirarki jajarannya demi penyelenggaraan pemilihan yang berkeadilan.

\footnotetext{
18 Baca Lampiran II UU Pemilu.

19 Bandingkan Pasal 24 ayat 2 UU Pilkada dengan Pasal 95 huruf i UU Pemilu.
} 


\section{DAFTAR PUSTAKA}

Buku:

Johnny Ibrahim. (2011). Teori dan Metode Penelitian Hukum Normatif. Cet. 4, Malang: Bayumedia Publishing, 2011.

Marwan Mas, Pengantar Ilmu Hukum, Jakarta: Ghalia Indonesia, 2004.

Prayudi, Ahmad Budiman, Aryojati Ardipandanto, Editor: Syamsuddin Haris, (2017), Dinamika Politik Pilkada Serentak, Jakarta: Pusat Penelitian Badan Keahlian DPR RI.

Prof. Dr. Suteki, S.H.,M.Hum., dan Galang Taufani, S.H.,M.H (2018). Metodologi Penelitian Hukum (Filsafat, Teori dan Praktik). Depok: Rajawali Pers.

R.A. Granita Ramadhani. (2009). Analisa Aspek Metodologi. FH UI.

Soerjono Soekanto dan Sri Mamudji. (2011). Penelitian Hukum Normatif. Suatu Tinjauan Singkat, Jakarta: Raja Grafindo Persada.

Syaukani, Affan Gaffar, M. Ryass Rasyid, Otonomi Daerah dalam Negara Kesatuan, Kerjasama Pusataka Pelajar dan Pusat Kajian Etika Politik dan Pemerintahan, Yogyakarta, 2002.

Wahiduddin Adams, "Harmonisasi Peraturan Perundang-Undangan di Indonesia", dalam Dinal Fedrian dkk, Dialektika Pembaharuan Sistem Hukum Indonesia, Jakarta: Komisi Yudisial Republik Indonesia, 2012.

\section{Jurnal:}

Depri Liber Sonata. (2014). "Metode Penelitian Hukum Normatif dan Empiris: Karakteristik Khas dari Metode Meneliti Hukum". Fiat Justisia Jurnal Ilmu Hukum, Volume 8 No. 1, Januari-Maret 2014.

Mohammad Agus Maulidi. (2017). Problematika Hukum Implementasi Putusan Final dan Mengikat Mahkamah Konstitusi Perspektif Negara Hukum. Jurnal Hukum Ius Quia Iustum No. 4 Vol. 24 Oktober 2017.

\section{Peraturan Perundang-undangan:}

Undang-Undang Republik Indonesia Nomor 7 Tahun 2017 tentang Pemilihan Umum.

Undang-Undang Republik Indonesia Nomor 10 Tahun 2016 tentang Perubahan Kedua atas Undang-Undang Nomor 1 Tahun 2015 tentang Penetapan Peraturan Pemerintah Pengganti Undang-Undang Nomor 1 Tahun 2014 tentang Pemilihan Gubernur, Bupati, dan Walikota Menjadi Undang-Undang.

Undang-Undang Nomor 1 Tahun 2015 tentang Penetapan Peraturan Pemerintah Pengganti Undang-Undang Nomor 1 Tahun 2014 tentang Pemilihan Gubernur, Bupati, dan Walikota.

Peraturan Komisi Pemilihan Umum Republik Indonesia Nomor 15 Tahun 2019 tentang Tahapan, Program dan Jadwal Penyelenggaraan Pemilihan Gubernur dan Wakil Gubernur, Bupati dan Wakil Bupati, dan/atau Walikota dan Wakil Walikota. 